\title{
Article
}

\section{Fighting Capital Flight in Africa: Evidence from Bundling and Unbundling Governance}

Asongu, Simplice and Nwachukwu, Jacinta Chikaodi

Available at http://clok.uclan.ac.uk/25146/

Asongu, Simplice and Nwachukwu, Jacinta Chikaodi ORCID: 0000-0003-29879242 (2017) Fighting Capital Flight in Africa: Evidence from Bundling and Unbundling Governance. Journal of Industry, Competition and Trade, 17 (3). pp. 305-323. ISSN 1566-1679

It is advisable to refer to the publisher's version if you intend to cite from the work. http://dx.doi.org/10.1007/s10842-016-0240-1

For more information about UCLan's research in this area go to http://www.uclan.ac.uk/researchgroups/ and search for < name of research Group>.

For information about Research generally at UCLan please go to http://www.uclan.ac.uk/research/

All outputs in CLoK are protected by Intellectual Property Rights law, including Copyright law. Copyright, IPR and Moral Rights for the works on this site are retained by the individual authors and/or other copyright owners. Terms and conditions for use of this material are defined in the policies page.

\section{CLoK}

Central Lancashire online Knowledge www.clok.uclan.ac.uk

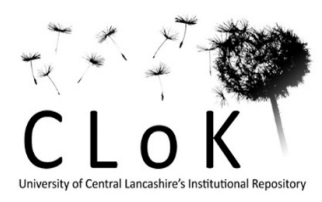




\section{A G D I Working Paper}

\section{$\mathrm{WP} / 16 / 047$}

Fighting Capital Flight in Africa: Evidence from Bundling and Unbundling Governance

Forthcoming in Journal of Industry, Competition and Trade

Simplice A. Asongu

African Governance and Development Institute,

P. O. Box 8413, Yaoundé, Cameroon

E-mails: asongusimplice@yahoo.com

asongus@afridev.org /

\section{Jacinta C. Nwachukwu}

School of Economics, Finance and Accounting, Faculty of Business, Environment and Society,

Coventry University

Priory Street, Coventry, CV1 5DH, UK

Email: jacinta.nwachukwu@ coventry.ac.uk 
Research Department

Fighting Capital Flight in Africa: Evidence from Bundling and Unbundling Governance

\title{
Simplice A. Asongu \& Jacinta C. Nwachukwu
}

April 2016

\begin{abstract}
This study investigates the effect of governance on capital flight by bundling and unbundling governance. The empirical evidence is based on 37 African countries for the period 19962010 and the Generalised Method of Moments. Governance is bundled by principal component analysis, namely: (i) political governance from political stability and 'voice and accountability'; (ii) economic governance from government effectiveness and regulation quality and (iii) institutional governance from corruption-control and the rule of law. The following findings are established. (i) Political stability and 'voice and accountability' reduce capital flight while the collective effect of political governance is not significant. (ii) Economic governance increases capital flight whereas the individual effects of regulation quality and government effectiveness are not significant. (iii) Corruption-control and institutional governance negatively affect capital flight whereas the impact of the rule of law is not significant. (iv) Taken together, Corruption-control is the most effective governance weapon in the fight against capital flight. (v) Priority in the Washington Consensus is more effective at fighting capital flight compared to the Beijing Model. Policy implications are discussed.
\end{abstract}

JEL Classification: C50; E62; F34; O55; P37

Keywords: Econometric modelling; Capital flight; Governance; Africa 


\section{Introduction}

Capital flight which is a consequence of the offshore financial economy is fundamentally traceable to poor governance (see Christensen, 2011; Gankou et al., 2016). Notwithstanding the evolving stream of research on governance (Musila \& Sigué, 2010; Kangoye, 2013) and capital flight (Mpenya et al., 2016; Ndiaye \& Siri, 2016), the literature remains unclear about how governance affects capital flight. Against this backdrop, the purpose of this study is to present a comprehensive assessment of the governance-'capital flight' nexus. For this purpose, we bundle and unbundle six governance indicators. The motivation for bundling governance indicators builds on evolving paradigms in the conception, definition and measurement of governance (see Asongu, 2016). For instance, it is inappropriate to employ the term political governance unless the variable underlying the term is a composite measurement of 'voice and accountability' and political stability/non-violence.

The inquiry is focused on Africa for two main reasons. First, the continent as a principal source of capital flight has experienced substantial levels of capital outflows over the past decades (Boyce \& Ndikumana, 2012a). According to the narrative, thirty-three SubSaharan African (SSA) countries lost about 814 billion US Dollars (in constant of 2010 US Dollar) during the period 1970-2010 (see Boyce \& Ndikumana, 2012a). This amount lost to the flight of capital surpasses official development assistance and foreign direct investment of respectively 659 and 306 billion US Dollars by the same countries in the sub-region during the same period. Shortage in financing has been documented to be the main cause of poverty and underdevelopment in Africa (see Bartels et al., 2009; Tuomi, 2011; Boyce \& Ndikumana, 2012a; Darley, 2012). The shortage of finance has hindered the socio-economic investment needed to alleviate extreme poverty. Accordingly, a recent report on attainment of the Millennium Development Goals (MDGs) by the World Bank has revealed that extreme poverty has been diminishing in all regions of the world with the exception of Africa, where 45 percent of countries in Sub-Saharan Africa were substantially off-track from attaining the MDG extreme poverty target (World Bank, 2015).

Second, contemporary African development literature on capital flight has failed to substantially capture the role of institutions in fighting the scourge. Accordingly, recent literature has focused on the lessons from case studies on the causes and consequences of capital flight (Ndikumana, 2016), inter alia: the relationship between capital flight and fiscal policy (Muchai \& Muchai, 2016); determinants of capital flight in Ethiopia (Geda \& Yimer, 2016) and Madagascar (Ramiandrisoa \& Rakotomanana, 2016); trade misinvoicing and 
capital flight in Zimbabwe (Kwaramba et al., 2016); the nexus between capital flight and natural resources in Cameroon (Mpenya et al., 2016); public social spending and capital flight in Congo-Brazzaville (Moulemvo, 2016) and linkages between capital flight and tax revenue in Burkina Faso (Ndiaye \& Siri, 2016).

In the light of the above, this study complements the literature by investigating the incidence of governance on capital flight with particular emphasis on the bundling and unbundling of institutions. It is of policy relevance to use composite governance indicators because concepts of governance have been used in the literature without an all-inclusive measurement. For example, Kangoye (2013) has used 'corruption-control' as 'governance'. Moreover, the concepts of institutional governance, economic governance and political governance have been employed in the literature without statistical validity (Kaufmann et al., 2007ab; Kurtz \& Schrank, 2007ab). We argue that it is inappropriate to employ the term 'economic governance' unless it translates an indicator that is composed of government effectiveness and regulation quality. We address this conceptual shortcoming by using nine bundled and unbundled governance indicators, namely: political governance (voice \& accountability and political stability/no violence); economic governance (government effectiveness and regulation quality) and institutional governance (corruption-control and the rule of law).

The rest of the study is structured as follows. Section 2 clarifies the concepts of governance and covers the theoretical underpinnings. The data and methodology are described in Section 3, while Section 4 presents the empirical results and related argument. Section 5 concludes with future research directions.

\section{Clarification of governance concepts and theoretical underpinnings}

\subsection{Clarification of concepts}

This section is organised into two strands: the first clarifies the concepts of governance while the second discusses the theoretical underpinnings. A multitude of definitions have been proposed to clarify the concept of governance. We accord with Asongu (2016) in discussing four definitions from recent literature. First, governance has been defined by Dixit (2009) as '...structure and functioning of the legal and social institutions that support economic activity and economic transactions by protecting property rights, enforcing contracts, and taking collective action to provide physical and organizational infrastructure, ${ }^{1}$ (p.5). Second,

\footnotetext{
${ }^{1}$ Emphasis on original.
} 
consistent with Fukuyama (2013), the governance concept can be consolidated with the comprehension of four main approaches to 'state quality', namely: capacity indicators that embody resource levels and professionalism, output indicators and political measures. Third, according to Tusalem (2015), governance is a phenomenon that encompasses: corruption, bureaucratic effectiveness, regulation quality and the rule of law. Fourth, notwithstanding this plethora of definitions, the most popular indicators in the literature are from Kaufmann et al. (2010). These include: (i) 'political governance' which is the election and replacement of political leaders (proxied with political stability/no violence and voice and accountability); (ii) 'institutional governance' which is the respect by the State and citizens of institutions that govern interactions between them (measured with corruption-control and the rule of law); and (iii) 'economic governance', which is defined as the formulation and implementation of policies that deliver public commodities (measured with government effectiveness and regulation quality).

In spite of criticisms on the quality of indicators used by Kaufmann et al. (2010), in scholarly circles, Kaufmann, Kraay and Mastruzzi have been promptly responding to the critics with rebuttals in order to confirm the quality of the World Bank indicators. One of the most interesting debates has been with Marcus Kurtz and Andrew Schrank. For lack of space, the interested reader is invited to consult the main streams underlying the debate, namely: measures and mechanisms (Kurtz \& Schrank, 2007a); a reply (Kaufmann et al., 2007a); a defense (Kurtz \& Schrank, 2007b) and a rejoinder (Kaufmann et al., 2007b).

\subsection{Governance and capital flight}

This section comprises three main strands, notably: the relationship between political governance and capital flight, the connection between economic governance and capital flight and the relationship between institutional governance and capital flight.

In the first strand on political governance, the political environment has been documented to be an important factor influencing capital flight because it is related to the loss/damage of assets as well as improvements in insurance premiums that are investmentrelated (see Collier et al., 2004; Davies, 2008; Ndikumana et al., 2015). When such features are associated with political stability and violence, it is very probable that investors are prompted to transfer their capital to environments with lower risks of investment. Moreover, if portfolio investors are persuaded that some national political institutions (e.g. executive accountability and competitive elections) are not conducive avenues for economic 
performance, they are more likely to withdraw their funds and transfer them to those countries where political institutions are credible and stable. In essence, a number of political characteristics shape the performance of foreign markets and security of claims related to foreign ownership (Lensink et al., 2000; Le \& Zak, 2006). For instance, with respect to foreign direct investment (FDI): in which an investor controls/own assets in a receiving nation, political risk could be negative on economic growth and long term investment.

In the light of the above, investors respond to political events they find unfavourable to their returns by disinvesting. Hence, direct impacts of political features such as accountability, democracy, political instability affect the amount of capital inflows into an economy. In essence, executives that are unaccountable could produce investment policies that are unpredictable, which affects capital flight.

As concerns the second strand, poor economic governance could produce an uncertain economic outlook that discourages investors from investing within an economy. This is essentially because investors have been documented to prefer investing in less uncertain economic climates (see Le Roux \& Kelsey, 2016; Kelsey \& Le Roux, 2016). In essence, bad economic governance can inflict considerable economic damages that influence investors' concern about asset valuation as well as confidence due to poor economic outlook. Thereby, from an investor's point of view, money and assets can quickly flow-out of a country in the face of bad governance. Poor economic governance can stifle macroeconomic performance, hence, discouraging investors because macroeconomic prospects are bleak.

From the government's perspective, bad economic governance can lead to capital flight if the formulation and implementation of policies designed to deliver public commodities are masterly tailored to siphon and deposit stolen funds in tax havens. This implies that in the absence of government effectiveness and regulation quality, government officials are more likely to devise policies that enable them to siphon funds and deposit them in tax havens.

In the third strand on institutional governance and capital flight, we argue that corruption-control and the rule of law influence both investors' confidence in an economy as well as the ability of government officials to siphon and deposit stolen funds abroad. Accordingly, investors would not put their money in an economy in which the respect of the rule of law is not optimal. In essence, they are less likely to invest if, in their opinion predation by the State can weaken overall economic performance, irrespective of whether they are directly affected by such predation. Respect of the rule of law ensures better 
protection of property rights and guarantees that foreigners do not need to be afraid of being expropriated of their invested assets. Such expropriation affects capital flight and discourages foreign investment. Moreover, countries with corrupt executives may not fully commit to respecting the ownership rights of investors.

\section{Data and Methodology}

\subsection{Data}

The study investigates a panel of 37 African countries with data from 1996 to 2010. There are two main sources to the data, namely: African Development Indicators of the World Bank and capital flight measurements from Boyce and Ndikumana (2012a). The study is for the period 1996-2010 because of data availability constraints. Accordingly, whereas good governance indicators from the World Bank are only available from 1996, the end year of the capital flight indicator is 2010 .

The capital flight outcome variable denotes capital flows between one country and the rest of the world that are unrecorded. The measurement of such flows begins from foreign exchange inflows that are considered in the Balance of Payments of a country, such that missing money (the variation between recorded inflows and outflows that are unrecorded) is documented in terms of 'net errors and omissions'. The highlighted conception and definition of capital flight has been substantially considered in recent capital flight literature (Weeks, 2015; Efobi \& Asongu, 2016).

The principal shortcoming in the capital flight measure is the fact that it is not comparable with other indicators, since, it is disclosed in constant 2010 US Dollar terms. In accordance with Asongu (2014), the concern is tackled by: (i) transforming current GDP into constant 2010 terms; (ii) dividing the corresponding value by 1000000 to obtain a 'GDP constant of 2010 USD (in millions) and (iii) finally dividing the capital flight data by the 'GDP constant of 2010 USD (in millions). Eventually, a capital flight measurement that is comparable with other indicators is obtained (see Appendix 2).

The six explanatory governance indicators from Kaufmann et al. (2010) are bundled in Section 3.1 by means of principal component analysis (PCA). The bundling exercise produces: (i) political governance (composed of political stability/non violence and voice \& accountability); (ii) economic governance (consisting of government effectiveness and regulation quality) and (iii) institutional governance (an embodiment of corruption-control and the rule of law). The six governance indicators from Kaufmann et al. (2010) have been 
used (though unbundled) in recent governance literature (see Gani, 2011; Yerrabit \& Hawkes, 2015; Andrés et al., 2015; Oluwatobi et al., 2015).

In order to avoid variable omission bias, we control for the following: the lagged dependent variable, trade openness, GDP growth, inflation, foreign direct investment (FDI) and public investment. There control variables have been substantially documented in the literature of capital flight (see Boyce \& Ndikumana, 1998, 2001, 2003, 2008, 2011, 2012ab; Weeks, 2012; Asongu, 2013, 2015). We expect the lagged values of capital flight to positively affect future values of capital flight in order to ascertain the capital flight trap. Economic prosperity in terms of economic growth can either increase or decrease capital flight depending on if the corresponding growth is either broad-based or concentrated within a few sectors of the economy (e.g. like heavy resource industries). On the one hand, economic growth that is broad-base could decrease capital flight because it confers a positive investment outlook. On the other hand, when growth is driven by a few extractive industries, it is most likely to be associated with capital flight. Very high inflation positively affects capital flight because, for the most part, it is linked to a negative investment/economic outlook and/or uncertainty in the return to investment. The intuition is in accordance with established evidence that investors prefer strategies of investment that are less ambiguous (Kelsey \& Le Roux, 2016; Le Roux \& Kelsey, 2016). Anticipated signs from FDI and trade are difficult to predict ex-ante because these signs are contingent on whether FDI is broad-based or restricted to a few economic sectors. Hence, this discourse is broadly in line with the previous narrative on economic growth. However, it is very probable that financial and trade globalisations are linked to capital flight because of, inter alia, opportunities for accounting practises like transfer mispricing (see Asongu \& Amankwah-Amoah, 2016; Ndikumana \& Sarr, 2016).

Appendix 1, Appendix 2 and Appendix 3 respectively present the definition of variables (with corresponding sources), the summary statistics and correlation matrix.

\subsection{Methodology}

\subsubsection{Principal Component Analysis (PCA)}

We employ the PCA in order to bundle government quality variables from Kaufmann et al. (2010) into three composite measurements, namely: political, institutional and economic governances. The PCA approach to bundling governance has been recently documented in African governance literature (Asongu \& Nwachukwu, 2016a). It is a technique that consists of reducing a set of highly correlated indicators into an uncorrelated set of small variables 
known as principal components (PCs). The derived PCs articulate a substantial variation or information from the original dataset.

Within the underlying PCA framework, the six indicators of good governance are reduced to political governance, economic governance and institutional governance. Political governance (a composition of political stability and voice \& accountability) is the election and replacement of political leaders. Economic governance (consisting of government effectiveness and regulation quality) is the formulation and implementation of policies that deliver public commodities. Institutional governance (entailing corruption-control and the rule of law) is the respect by citizens and the State of institutions that govern interactions between them.

The selection of PCs is based on the Jolliffe (2002) and Kaiser (1974) criterion. These authors have recommended that only common factors that have an eigenvalue which is higher than the mean or one should be retained. As shown in Table 1, political governance (Polgov) which represents about $83.50 \%$ of information from 'voice and accountability' and political stability has an eigenvalue of 1.671, economic governance (Ecogov) which reflects about $93.90 \%$ of information from government effectiveness and regulation quality has an eigenvalue of 1.878 while institutional governance (Instgov) that represents about $93.00 \%$ of information from corruption-control and the rule of law has an eigenvalue of 1.861 .

It is important to note that eigenvalues reflect eigenvectors associated with the PCs. For instance, the first eigenvector of a correlation matrix shows the maximum variance in the data. The eigenvector is the first PC. Hence, a PC provides a new orthogonal basis for uncorrelated data points and each PC is a linear combination of original indicators that have coordinates in the fundamental basis. The maximum variance can also be understood as common information that is contained in constituents of the PC.

Table 1: Principal Component Analysis (PCA) for Composite Governance

\begin{tabular}{|c|c|c|c|c|c|c|c|c|c|}
\hline \multirow{2}{*}{$\begin{array}{c}\text { Principal } \\
\text { Components }\end{array}$} & \multicolumn{6}{|c|}{ Component Matrix(Loadings) } & \multirow[t]{2}{*}{ Proportion } & \multirow{2}{*}{$\begin{array}{l}\text { Cumulative } \\
\text { Proportion }\end{array}$} & \multirow{2}{*}{$\begin{array}{l}\text { Eigen } \\
\text { Value }\end{array}$} \\
\hline & VA & PS & $\mathbf{R Q}$ & GE & $\mathbf{R L}$ & $\mathbf{C C}$ & & & \\
\hline First PC (Polgov) & 0.707 & 0.707 & --- & --- & --- & --- & 0.835 & 0.835 & 1.671 \\
\hline Second PC & -0.707 & 0.707 & --- & --- & --- & --- & 0.164 & 1.000 & 0.328 \\
\hline First PC (Ecogov) & --- & --- & 0.707 & 0.707 & --- & --- & 0.939 & 0.939 & 1.878 \\
\hline Second PC & --- & --- & -0.707 & 0.707 & --- & --- & 0.060 & 1.000 & 0.121 \\
\hline First PC (Instgov) & --- & --- & --- & --- & 0.707 & 0.707 & 0.930 & 0.930 & 1.861 \\
\hline Second PC & --- & --- & --- & --- & -0.707 & 0.707 & 0.069 & 1.000 & 0.138 \\
\hline
\end{tabular}

P.C: Principal Component. VA: Voice \& Accountability. RL: Rule of Law. R.Q: Regulation Quality. GE: Government Effectiveness. PS Political Stability. CC: Control of Corruption. G.Gov (General Governance): First PC of VA, PS, RQ, GE, RL \& CC. Polgov (Political 
Governance): First PC of VA \& PS. Ecogov (Economic Governance): First PC of RQ \& GE. Instgov (Institutional Governance): First PC of RL \& CC.

It is important to engage some pertinent issues that may arise with regards to regressors that are obtained from initial regressions. In essence, as recently documented by Asongu and Nwachukwu (2016a), issues are associated with the consistency and efficiency of estimates as well as the validity of associated inferences. According to Pagan (1984, p.242), whereas two-step estimators are consistent and efficient, only few valid inferences can be made. This caution is an accordance with a recent strand of literature pertaining to the concerns: Westerlund and Urbain (2013a); Ba and Ng (2006); McKenzie and McAleer (1997) and Oxley and McAleer (1993).

Westerlund and Urbain (2012, 2013b) have documented issues on the inferential quality of variables that are derived from PCA. The authors have built on a stream of previous studies on the subject (Pesaran, 2006; Stock \& Watson, 2002; Bai, 2003; Bai, 2009; Greenaway-McGrevy et al., 2012) to conclude that normal inferences are possible with PCaugmented regressors, provided that the estimated parameters converge to their real values at the rate $\sqrt{N T}$, (with $\mathrm{T}$ being the number of time series and $\mathrm{N}$ denoting cross-section observations). They have gone further to clarify that, in order for the suggested convergence to take place, $\mathrm{N}$ and $\mathrm{T}$ need to be sufficiently large. But there is no indication as to how 'large is large'. Regarding the specific context of this paper, we are confronted with two major issues. On the one hand, $\mathrm{N}$ cannot be increased further because we are engaging all the 37 countries for which capital flight is available. On the other hand, $\mathrm{T}$ can only be situated between 1996 and 2010 because: good governance indicators only date from 1996 and capital flight data ends in 2010. In a summary, we argue that valid inferences are feasible because Asongu and Nwachukwu (2016a) have recently established valid inferences using governance indicators that are lower in terms of $\mathrm{T}$ and $\mathrm{N}$.

\subsubsection{Estimation technique}

The choice of the Generalised Method of Moments (GMM) empirical strategy is motivated by at least five factors: whereas the first-two are fundamental requirements, the last-three are related advantages. The strategy enables the study to account for the capital flight trap given that, the criterion for persistence in capital flight is fulfilled. In essence, the correlation between capital flight and its first lag is 0.867 , which is above 0.800 considered as the criterion needed to ascertain persistence in the outcome variable. The $\mathrm{T}$ (or 5) $<\mathrm{N}$ (or 37) 
criterion for the use of the GMM estimation approach is met since the number of time series in each cross section is lower than the number of cross sections. The estimation approach controls for endogeneity in all regressors by employing instrumented regressors as well as controlling for time invariant omitted variables. Biases in the difference GMM approach are handled by the system GMM version. Specifications also take cross-country differences into account.

It is for the fourth reason above that the system GMM estimator (from Arellano \& Bond, 1995; Blundell \& Bond, 1998) has been documented by Bond et al. (2001, pp.3-4) to have better properties than the difference estimator (from Arellano \& Bond, 1991). The system approach adopted by this study is the Roodman (2009ab) extension of Arellano and Bover (1995) which instead of employing differences uses forward orthogonal deviations. This extension has better properties because it has been established to limit instrument proliferation and/or avoid over-identification (see Baltagi, 2008; Love \& Zicchino, 2006). A two-step specification is chosen because it controls for heteroscedasticity. Accordingly, the one-step approach is consistent with homoscedasticity.

The following equations in levels (1) and first difference (2) summarize the standard system GMM estimation procedure.

$$
\begin{aligned}
\operatorname{Cap}_{i, t}=\sigma_{0}+\sigma_{1} & \operatorname{Cap}_{i, t-\tau}+\sigma_{2} \operatorname{Gov}_{i, t}+\sum_{h=1}^{5} \delta_{h} W_{h, i, t-\tau}+\eta_{i}+\xi_{t}+\varepsilon_{i, t} \\
\operatorname{Cap}_{i, t}-\operatorname{Cap}_{i, t-\tau}= & \sigma_{0}+\sigma_{1}\left(\operatorname{Cap}_{i, t-\tau}-\operatorname{Cap}_{i, t-2 \tau}\right)+\sigma_{2}\left(\operatorname{Gov}_{i, t}-\operatorname{Gov}_{i, t-\tau}\right) \\
& +\sum_{h=1}^{5} \delta_{h}\left(W_{h, i, t-\tau}-W_{h, i, t-2 \tau}\right)+\left(\xi_{t}-\xi_{t-\tau}\right)+\varepsilon_{i, t-\tau}
\end{aligned}
$$

Where: $\operatorname{Cap}_{i, t}$ is capital flight of country $i$ at period $t ; \alpha$ is a constant; $\tau$ represents the coefficient of autoregression; Gov, denotes governance which may be political, economic or institutional; $W$ is the vector of control variables (Trade, Growth, Inflation, FDI and Public Investment), $\eta_{i}$ is the country-specific effect, $\xi_{t}$ is the time-specific constant and $\varepsilon_{i, t}$ the error term.

\subsubsection{Identification, simultaneity and exclusion restrictions}

It is important to engage exclusion restrictions and identification. Consistent with recent studies (see Dewan \& Ramaprasad, 2014; Asongu \& Nwachukwu, 2016b), all independent variables are suspected endogenous or predetermined whereas the time-invariant omitted variables are acknowledged as strictly exogenous. This is essentially because it is not 
feasible for time-invariant omitted variables to become endogenous in first-difference (see Roodman, 2009b). Hence, the approach for treating ivstyle (years) is 'iv(years, eq(diff))' while the gmmstyle is used for suspected endogenous variables.

In order to address the concern of simultaneity, lagged regressors are employed as instruments for forward differenced variables. Helmet transformations are also employed for the regressors in order to eliminate fixed effects that could affect the investigated nexuses (Arellano \& Bover, 1995; Love \& Zicchino, 2006). Such transformations entail the use of forward mean-differencing of the indicators: contrary to the process of subtracting previous observations from present one (see Roodman, 2009b, p. 104), the average of all future observations is deducted from the indicators. This transformation ensures orthogonal or parallel conditions between lagged values and forward-differenced variables. Irrespective of the number of lags, the loss of data is minimised by computing the underlying transformation for all observations with the exception of the last observation in cross sections: "And because lagged observations do not enter the formula, they are valid as instruments" (Roodman (2009b, p. 104).

In view of the above, time invariant omitted variables influence capital flight exclusively via the suspected endogenous or predetermined variables. Moreover, the statistical validity of the exclusion restriction is investigated with the Difference in Hansen Test (DHT) for the validity of instruments. In essence, for the time invariant variables to explain capital flight exclusively through the suspected endogenous variables, the alternative hypothesis of the test should be rejected. It is important to note that while in a standard instrumental variable (IV) approach, failure to reject the null hypothesis of the Sargan Overidentifying Restrictions (OIR) test indicates that the instruments do not elucidate the outcome variable beyond suspected endogenous variables (see Beck et al., 2003; Asongu \& Nwachukwu, 2016c), with the GMM approach that uses forward orthogonal deviations, the information criterion that is employed to assess whether time invariant omitted variables exhibit strict exogeneity is the DHT. Therefore in the light of these clarifications, in the reported findings below, the hypothesis of exclusion restriction is validated if the null hypothesis of the DHT associated with IV(year, eq(diff)) is not rejected. 


\section{Empirical results}

\subsection{Presentation of results}

Table 2, Table 3 and Table 4 respectively present findings corresponding to political governance, economic governance and institutional governance. Four principal information criteria are employed to assess the validity of the GMM model with forward orthogonal deviations $^{2}$. The following findings can be established for Table 2. Political stability and 'voice and accountability' reduce capital flight while the effect of political governance is not significant.

The following findings can be established from Table 3 on the nexus between economic governance and capital flight. Whereas regulation quality positively affects capital flight, the corresponding specification is not valid because of invalid instruments. Economic governance increases capital flight whereas the effect of government effectiveness is not significant.

The following findings can be established from Table 4 on the nexus between institutional governance and capital flight. Corruption-control and institutional governance negatively affect capital flight whereas the impact of the rule of law is not significant. For all three tables, most of the significant control variables have anticipated signs and the capital flight trap is confirmed because past capital flight positively affects future capital flight.

\footnotetext{
2 "First, the null hypothesis of the second-order Arellano and Bond autocorrelation test (AR(2)) in difference for the absence of autocorrelation in the residuals should not be rejected. Second the Sargan and Hansen overidentification restrictions (OIR) tests should not be significant because their null hypotheses are the positions that instruments are valid or not correlated with the error terms. In essence, while the Sargan OIR test is not robust but not weakened by instruments, the Hansen OIR is robust but weakened by instruments. In order to restrict identification or limit the proliferation of instruments, we have ensured that instruments are lower than the number of cross-sections in most specifications. Third, the Difference in Hansen Test (DHT) for exogeneity of instruments is also employed to assess the validity of results from the Hansen OIR test. Fourth, a Fischer test for the joint validity of estimated coefficients is also provided" (Asongu \& De Moor, 2016, p.9)
} 
Table 2: Capital flight and political governance

\begin{tabular}{|c|c|c|c|c|c|c|}
\hline \multirow{3}{*}{ Constant } & \multicolumn{6}{|c|}{ Dependent variable: Capital Flight } \\
\hline & \multicolumn{2}{|c|}{ Political Stability } & \multicolumn{2}{|c|}{ Voice and Accountability } & \multicolumn{2}{|c|}{ Political Governance } \\
\hline & $\begin{array}{l}4.895 * * * \\
(0.000)\end{array}$ & $\begin{array}{l}5.377 * * * \\
(0.000)\end{array}$ & $\begin{array}{l}5.091 * * * \\
(0.000)\end{array}$ & $\begin{array}{l}4.769 * * * \\
(0.00)\end{array}$ & $\begin{array}{l}4.873 * * * \\
(0.000)\end{array}$ & $\begin{array}{l}4.817 * * * \\
(0.000)\end{array}$ \\
\hline Capital Flight (-1) & $\begin{array}{l}0.494 * * * \\
(0.000)\end{array}$ & $\begin{array}{l}0.516 * * * \\
(0.000)\end{array}$ & $\begin{array}{l}0.492 * * * \\
(0.000)\end{array}$ & $\begin{array}{l}0.569 * * * \\
(0.000)\end{array}$ & $\begin{array}{l}0.504 * * * \\
(0.000)\end{array}$ & $\begin{array}{l}0.581 * * * \\
(0.000)\end{array}$ \\
\hline Political Stability & $\begin{array}{l}-0.115^{*} \\
(0.077)\end{array}$ & $\begin{array}{l}-0.047 * \\
(0.077)\end{array}$ & --- & --- & --- & --- \\
\hline Voice \& Accountability & --- & --- & $\begin{array}{l}0.044 \\
(0.785)\end{array}$ & $\begin{array}{l}-0.131 * \\
(0.063)\end{array}$ & --- & --- \\
\hline Political Governance & --- & --- & --- & --- & $\begin{array}{l}-0.049 \\
(0.467)\end{array}$ & $\begin{array}{l}-0.036 \\
(0.304)\end{array}$ \\
\hline Trade Openness & $\begin{array}{l}0.0002 \\
(0.868)\end{array}$ & $\begin{array}{l}-0.001 \\
(0.340)\end{array}$ & $\begin{array}{l}-0.001 \\
(0.485)\end{array}$ & $\begin{array}{l}-0.0008 \\
(0.554)\end{array}$ & $\begin{array}{l}-0.0001 \\
(0.919)\end{array}$ & $\begin{array}{l}0.001 \\
(0.216)\end{array}$ \\
\hline GDP growth & $\begin{array}{l}0.005 \\
(0.510)\end{array}$ & $\begin{array}{l}-0.014 * * \\
(0.027)\end{array}$ & $\begin{array}{l}0.011 \\
(0.231)\end{array}$ & $\begin{array}{l}-0.015 * * * \\
(0.003)\end{array}$ & $\begin{array}{l}0.011 \\
(0.262)\end{array}$ & $\begin{array}{l}-0.026 * * * \\
(0.000)\end{array}$ \\
\hline Inflation & --- & $\begin{array}{l}0.003 * * * \\
(0.000)\end{array}$ & --- & $\begin{array}{l}\mathbf{0 . 0 0 2} * * * \\
(\mathbf{0 . 0 0 0 )}\end{array}$ & --- & $\begin{array}{l}0.002 * * * \\
(0.000)\end{array}$ \\
\hline Foreign Direct Investment & --- & $\begin{array}{l}-0.016 * * * \\
(0.000)\end{array}$ & --- & $\begin{array}{l}-0.014 * * * \\
(0.000)\end{array}$ & --- & $\begin{array}{l}-0.019 * * * \\
(0.000)\end{array}$ \\
\hline Public Investment & --- & $\begin{array}{l}-0.005 \\
(0.562)\end{array}$ & --- & $\begin{array}{l}-0.009 \\
(0.456)\end{array}$ & --- & $\begin{array}{l}-0.032 * * \\
(0.015)\end{array}$ \\
\hline $\operatorname{AR}(1)$ & $(0.153)$ & $(0.042)$ & $(0.202)$ & $(0.083)$ & $(0.194)$ & $(0.064)$ \\
\hline $\mathrm{AR}(2)$ & $(0.299)$ & $(0.471)$ & $(0.458)$ & $(0.686)$ & $(0.421)$ & $(0.936)$ \\
\hline Sargan OIR & $(0.613)$ & $(0.005)$ & $(0.686)$ & $(0.002)$ & $(0.766)$ & $(0.005)$ \\
\hline Hansen OIR & $(0.524)$ & $(0.639)$ & $(0.492)$ & $(0.658)$ & $(0.486)$ & $(0.773)$ \\
\hline $\begin{array}{l}\text { DHT for instruments } \\
\text { (a)Instruments in levels }\end{array}$ & & & & & & \\
\hline $\mathrm{H}$ excluding group & $(0.510)$ & $(0.825)$ & $(0.231)$ & $(0.357)$ & $(0.492)$ & $(0.234)$ \\
\hline $\begin{array}{l}\text { Dif(null, H=exogenous) } \\
\text { (b) IV (years, eq(diff)) }\end{array}$ & $(0.453)$ & $(0.418)$ & $(0.643)$ & $(0.745)$ & $(0.420)$ & $(0.942)$ \\
\hline H excluding group & $(0.615)$ & $(0.568)$ & $(0.733)$ & $(0.486)$ & $(0.716)$ & $(0.443)$ \\
\hline Dif(null, $\mathrm{H}=$ =xogenous) & $(0.294)$ & $(0.601)$ & (0.169) & $(0.930)$ & $(0.175)$ & (1.000) \\
\hline Fisher & $38.17 * * *$ & $9614.00 * * *$ & $49.77 * * *$ & $11287.04 * * *$ & $35.55 * * *$ & $28146.35 * * *$ \\
\hline Instruments & 18 & 30 & 18 & 30 & 18 & 30 \\
\hline Countries & 29 & 27 & 29 & 27 & 29 & 27 \\
\hline Observations & 95 & 81 & 95 & 81 & 95 & 81 \\
\hline
\end{tabular}

***,***: significance levels of 10\%, 5\% and 1\% respectively. DHT: Difference in Hansen Test for Exogeneity of Instruments Subsets. Dif: Difference. OIR: Over-identifying Restrictions Test. The significance of bold values is twofold. 1) The significance of estimated coefficients and the Fisher statistics. 2) The failure to reject the null hypotheses of: a) no autocorrelation in the AR(1) and $\operatorname{AR}(2)$ tests and; b) the validity of the instruments in the Sargan OIR test. na: not applicable due to the insignificance of marginal effects. 
Table 3: Capital flight and economic governance

\begin{tabular}{|c|c|c|c|c|c|c|}
\hline \multirow{3}{*}{ Constant } & \multicolumn{6}{|c|}{ Dependent variable: Capital Flight } \\
\hline & \multicolumn{2}{|c|}{ Regulation Quality } & \multicolumn{2}{|c|}{ Government Effectiveness } & \multicolumn{2}{|c|}{ Economic Governance } \\
\hline & $\begin{array}{l}3.242 * * * \\
(0.000)\end{array}$ & $\begin{array}{l}4.717 * * * \\
(0.000)\end{array}$ & $\begin{array}{l}4.113 * * * \\
(0.000)\end{array}$ & $\begin{array}{l}5.237 * * * \\
(0.000)\end{array}$ & $\begin{array}{l}3.164 * * * \\
(0.000)\end{array}$ & $\begin{array}{l}3.480 * * * \\
(\mathbf{0 . 0 0 0 )}\end{array}$ \\
\hline Capital Flight (-1) & $\begin{array}{l}0.681 * * * \\
(0.000)\end{array}$ & $\begin{array}{l}0.580 * * * \\
(\mathbf{0 . 0 0 0 )}\end{array}$ & $\begin{array}{l}0.582 * * * \\
(0.000)\end{array}$ & $\begin{array}{l}0.535 * * * \\
(0.000)\end{array}$ & $\begin{array}{l}0.676 * * * \\
(0.000)\end{array}$ & $\begin{array}{l}0.648 * * * \\
(0.000)\end{array}$ \\
\hline Regulation Quality & $\begin{array}{l}\mathbf{0 . 3 7 8}^{* *} \\
(0.014)\end{array}$ & $\begin{array}{l}0.020 \\
(0.728)\end{array}$ & --- & --- & --- & --- \\
\hline Government Effectiveness & --- & --- & $\begin{array}{l}-0.120 \\
(0.164)\end{array}$ & $\begin{array}{l}-0.040 \\
(0.585)\end{array}$ & --- & --- \\
\hline Economic Governance & --- & --- & --- & --- & $\begin{array}{l}0.058 \\
(0.320)\end{array}$ & $\begin{array}{l}0.063 * \\
(0.054)\end{array}$ \\
\hline Trade Openness & $\begin{array}{l}0.0007 \\
(0.706)\end{array}$ & $\begin{array}{l}0.0006 \\
(0.702)\end{array}$ & $\begin{array}{l}-0.0009 \\
(0.554)\end{array}$ & $\begin{array}{l}0.0002 \\
(0.828)\end{array}$ & $\begin{array}{l}-0.0002 \\
(0.879)\end{array}$ & $\begin{array}{l}0.0009 \\
(0.494)\end{array}$ \\
\hline GDP growth & $\begin{array}{l}-0.003 \\
(0.589)\end{array}$ & $\begin{array}{l}-0.016 * * * \\
(0.004)\end{array}$ & $\begin{array}{l}-0.00008 \\
(0.992)\end{array}$ & $\begin{array}{l}-0.019 * * * \\
(0.000)\end{array}$ & $\begin{array}{l}-0.002 \\
(0.701)\end{array}$ & $\begin{array}{l}-0.016 * * * \\
(0.000)\end{array}$ \\
\hline Inflation & -- & $\begin{array}{l}0.003 * * * \\
(\mathbf{0 . 0 0 0 )}\end{array}$ & --- & $\begin{array}{l}0.022 * * * \\
(0.000)\end{array}$ & --- & $\begin{array}{l}0.003 * * * \\
(0.000)\end{array}$ \\
\hline Foreign Direct Investment & --- & $\begin{array}{l}-0.020 * * * \\
(0.000)\end{array}$ & --- & $\begin{array}{l}-0.019 * * * \\
(0.000)\end{array}$ & --- & $\begin{array}{l}-0.020 * * * \\
(0.000)\end{array}$ \\
\hline Public Investment & --- & $\begin{array}{l}-0.015 \\
(0.161)\end{array}$ & --- & $\begin{array}{l}-0.022 * * \\
(0.047)\end{array}$ & --- & $\begin{array}{l}-0.016 \\
(0.101)\end{array}$ \\
\hline $\operatorname{AR}(1)$ & $(0.116)$ & $(0.043)$ & $(\mathbf{0 . 1 4 3})$ & $(0.046)$ & $(0.118)$ & $(0.020)$ \\
\hline $\mathrm{AR}(2)$ & $(0.116)$ & $(0.565)$ & $(0.354)$ & $(0.623)$ & $(\mathbf{0 . 1 3 5})$ & $(0.247)$ \\
\hline Sargan OIR & $(0.263)$ & $(\mathbf{0 . 0 2 0})$ & $(0.697)$ & $(0.022)$ & $(0.408)$ & $(0.006)$ \\
\hline Hansen OIR & $(0.072)$ & $(0.631)$ & $(0.362)$ & $(0.762)$ & $(\mathbf{0 . 0 8 3})$ & $(0.607)$ \\
\hline $\begin{array}{l}\text { DHT for instruments } \\
\text { (a)Instruments in levels }\end{array}$ & & & & & & \\
\hline $\mathrm{H}$ excluding group & $(0.298)$ & $(0.288)$ & $(0.263)$ & $(0.216)$ & $(0.379)$ & $(0.328)$ \\
\hline $\begin{array}{l}\text { Dif(null, H=exogenous) } \\
\text { (b) IV (years, eq(diff)) }\end{array}$ & $(0.062)$ & $(0.771)$ & $(\mathbf{0 . 4 3 3})$ & $(0.944)$ & $(0.060)$ & $(0.708)$ \\
\hline H excluding group & $(0.492)$ & $(0.502)$ & $(0.623)$ & $(0.386)$ & $(0.297)$ & $(0.467)$ \\
\hline Dif(null, $\mathrm{H}=$ =xogenous) & $(0.013)$ & $(0.782)$ & $(\mathbf{0 . 1 3 1})$ & (1.000) & $(0.042)$ & $(0.816)$ \\
\hline Fisher & $87.59 * * *$ & $762694 * * *$ & $55.60 * * *$ & $216945 * * *$ & $60.32 * * *$ & $4297.55^{* * * *}$ \\
\hline Instruments & 18 & 30 & 18 & 30 & 18 & 30 \\
\hline Countries & 29 & 27 & 29 & 27 & 29 & 27 \\
\hline Observations & 95 & 81 & 95 & 81 & 95 & 81 \\
\hline
\end{tabular}

***,***: significance levels of 10\%, 5\% and 1\% respectively. DHT: Difference in Hansen Test for Exogeneity of Instruments Subsets. Dif: Difference. OIR: Over-identifying Restrictions Test. The significance of bold values is twofold. 1) The significance of estimated coefficients and the Fisher statistics. 2) The failure to reject the null hypotheses of: a) no autocorrelation in the AR(1) and $\operatorname{AR}(2)$ tests and; b) the validity of the instruments in the Sargan OIR test. na: not applicable due to the insignificance of marginal effects. 


\begin{tabular}{|c|c|c|c|c|c|c|}
\hline \multirow{3}{*}{ Constant } & \multicolumn{6}{|c|}{ Dependent variable: Capital Flight } \\
\hline & \multicolumn{2}{|c|}{ Rule of Law } & \multicolumn{2}{|c|}{ Corruption Control } & \multirow{2}{*}{$\begin{array}{l}\text { Institutional } \\
\mathbf{3 . 5 5 0} * * * * \\
(\mathbf{0 . 0 0 0 )}\end{array}$} & \multirow{2}{*}{$\begin{array}{l}\text { Governance } \\
\mathbf{4 . 8 1 7 * * *} \\
(\mathbf{0 . 0 0 0 )}\end{array}$} \\
\hline & $\begin{array}{l}3.470 * * * \\
(\mathbf{0 . 0 0 0 )}\end{array}$ & $\begin{array}{l}4.717 * * * * \\
(0.000)\end{array}$ & $\begin{array}{l}3.956 * * * \\
(0.000)\end{array}$ & $\begin{array}{l}4.308 * * * \\
(0.000)\end{array}$ & & \\
\hline Capital Flight (-1) & $\begin{array}{l}0.645^{* * * *} \\
(0.000)\end{array}$ & $\begin{array}{l}0.580 * * * \\
(0.000)\end{array}$ & $\begin{array}{l}0.582 * * * \\
(0.000)\end{array}$ & $\begin{array}{l}0.620 * * * \\
(0.000)\end{array}$ & $\begin{array}{l}0.648 * * * \\
(0.000)\end{array}$ & $\begin{array}{l}0.581 * * * \\
(0.000)\end{array}$ \\
\hline Rule of Law & $\begin{array}{l}-0.025 \\
(0.867)\end{array}$ & $\begin{array}{l}0.020 \\
(0.728)\end{array}$ & --- & --- & --- & --- \\
\hline Corruption Control & --- & --- & $\begin{array}{l}-0.408 * * \\
(0.021)\end{array}$ & $\begin{array}{l}-0.062 \\
(0.392)\end{array}$ & --- & --- \\
\hline Institutional Governance & --- & --- & --- & --- & $\begin{array}{l}-0.157 * * \\
(0.023)\end{array}$ & $\begin{array}{l}-0.036 \\
(0.304)\end{array}$ \\
\hline Trade Openness & $\begin{array}{l}-0.0005 \\
(0.734)\end{array}$ & $\begin{array}{l}0.0006 \\
(0.702)\end{array}$ & $\begin{array}{l}-0.00007 \\
(0.940)\end{array}$ & $\begin{array}{l}0.001 \\
(0.184)\end{array}$ & $\begin{array}{l}-0.0004 \\
(0.712)\end{array}$ & $\begin{array}{l}0.001 \\
(0.216)\end{array}$ \\
\hline GDP growth & $\begin{array}{l}0.002 \\
(0.693)\end{array}$ & $\begin{array}{l}-0.016 * * * \\
(0.014)\end{array}$ & $\begin{array}{l}-0.019 * * \\
(0.045)\end{array}$ & $\begin{array}{l}-0.024 * * * \\
(0.000)\end{array}$ & $\begin{array}{l}-0.012 \\
(0.147)\end{array}$ & $\begin{array}{l}-0.026 * * * \\
(0.000)\end{array}$ \\
\hline Inflation & --- & $\begin{array}{l}\mathbf{0 . 0 0 3} * * * \\
(\mathbf{0 . 0 0 0 )}\end{array}$ & --- & $\begin{array}{l}0.002 * * * \\
(0.000)\end{array}$ & --- & $\begin{array}{l}0.002 * * * \\
(0.000)\end{array}$ \\
\hline Foreign Direct Investment & --- & $\begin{array}{l}-\mathbf{0 . 0 2 0} * * * \\
(\mathbf{0 . 0 0 0 )}\end{array}$ & --- & $\begin{array}{l}-0.017 * * * \\
(0.000)\end{array}$ & --- & $\begin{array}{l}-0.019 * * * \\
(0.000)\end{array}$ \\
\hline Public Investment & --- & $\begin{array}{l}-0.015 \\
(0.161)\end{array}$ & --- & $\begin{array}{l}-0.026 * \\
(0.051)\end{array}$ & --- & $\begin{array}{l}-\mathbf{0 . 0 3 2} * * \\
(\mathbf{0 . 0 1 5})\end{array}$ \\
\hline $\operatorname{AR}(1)$ & $(0.161)$ & $(0.043)$ & $(0.057)$ & $(0.069)$ & $(0.077)$ & $(0.064)$ \\
\hline $\operatorname{AR}(2)$ & $(0.266)$ & $(0.565)$ & $(0.771)$ & $(\mathbf{0 . 7 8 0})$ & $(0.341)$ & $(\mathbf{0 . 9 3 6 )}$ \\
\hline Sargan OIR & $(0.718)$ & $(0.020)$ & $(0.770)$ & $(0.001)$ & $(0.724)$ & $(0.005)$ \\
\hline Hansen OIR & $(0.344)$ & $(0.631)$ & $(0.474)$ & $(0.663)$ & $(0.482)$ & $(0.773)$ \\
\hline $\begin{array}{l}\text { DHT for instruments } \\
\text { (a)Instruments in levels }\end{array}$ & & & & & & \\
\hline H excluding group & (0.193) & $(0.288)$ & $(0.160)$ & $(0.235)$ & $(0.259)$ & $(\mathbf{0 . 2 3 4})$ \\
\hline $\begin{array}{l}\text { Dif(null, H=exogenous) } \\
\text { (b) IV (years, eq(diff)) }\end{array}$ & $(0.489)$ & $(0.771)$ & $(0.727)$ & $(\mathbf{0 . 8 5 2})$ & $(\mathbf{0 . 5 9 8})$ & $(0.942)$ \\
\hline H excluding group & $(0.426)$ & $(0.502)$ & $(0.418)$ & $(0.353)$ & $(0.708)$ & $(0.443)$ \\
\hline Dif(null, $\mathrm{H}=$ exogenous) & $(0.246)$ & $(0.782)$ & $(0.473)$ & (1.000) & $(0.177)$ & (1.000) \\
\hline Fisher & $45.82 * * *$ & $62694 * * *$ & $43.88 * * *$ & $7472.44 * * *$ & $47.68 * * *$ & $28146 * * *$ \\
\hline Instruments & 18 & 30 & 18 & 30 & 18 & 30 \\
\hline Countries & 29 & 27 & 29 & 27 & 29 & 27 \\
\hline Observations & 95 & 81 & 95 & 81 & 95 & 81 \\
\hline
\end{tabular}

*,**,***: significance levels of 10\%, 5\% and 1\% respectively. DHT: Difference in Hansen Test for Exogeneity of Instruments' Subsets. Dif: Difference. OIR: Over-identifying Restrictions Test. The significance of bold values is twofold. 1) The significance of estimated coefficients and the Fisher statistics. 2) The failure to reject the null hypotheses of: a) no autocorrelation in the AR(1) and AR(2) tests and; b) the validity of the instruments in the Sargan OIR test. na: not applicable due to the insignificance of marginal effects.

\subsection{Further discussion and policy implications}

\subsubsection{Contributions in the conception, definition and measurement of governance}

The practical contributions can be viewed from two perspectives, namely, the: insignificance of bundled governances and significance of bundled governance. From the first viewpoint, we have established that whereas the role of political governance is not significant, the corresponding role of its constituent components (political stability and 'voice \& 
accountability') is significant at mitigating capital flight. It follows that the election and replacement of political leaders per se does not reduce capital flights. There are two angles to the second perspective. On the one hand, economic governance increases capital flight whereas the effects of regulation quality and government effectiveness are not significant. On the other hand, corruption-control and institutional governance negatively affect capital flight whereas the impact of the rule of law is not significant.

In the light of the above: (i) the formulation and implementation of policies that deliver public commodities affect capital flight while constituents of such formulation and implementation of polices do not and (ii) the effect on institutional governance on capital flight is driven by corruption-control. The above discourse clearly articulates the interest of these findings in terms of bundling and unbundling governance. In essence, it shows that a governance concept could: behave differently from its constituents and be driven by specific constituent components. Having discussed the contribution of the study to the conception, definition and measurement of governance, we now engage the signs of estimated coefficients in terms of the Washington Consensus versus the Beijing Model and relevance of corruptioncontrol as the best governance tool in the fight against capital flight.

\subsubsection{The Washington Consensus versus the Beijing Model in the fighting capital flight}

The findings can be further elucidated with differences in the two dominant models of development, namely: the Washington Consensus (which prioritizes political governance) and the Beijing Model (which prioritizes economic governance). Priorities of the dominant development models build on Asongu and Ssozi (2016, p.44) who have surveyed about 110 recently published studies on Sino-African relations to define the Beijing Model as " $d e$ emphasized democracy, state capitalism, and priority in economic rights" and the Washington Consensus as "liberal democracy, private capitalism, and priority in political rights".

The emphasis on economic governance versus political governance is essential in capital flight for a fundamental reason. The two dominant models of development influence foreign investment and capital flows to African countries (Kolstad \& Wiig, 2011; Lin, \& Farrell, 2013; Drogendijk \& Blomkvist, 2013). Accordingly, whereas capital flows from Western countries (that are sympathetic to the Washington Consensus) is based on the economics of pre-conditions such as respect for human rights and improvements in democratic standards, capital flows from China (who champions the Beijing Model) is not 
founded on the principle of conditionality, essentially because the country has a foreign policy of non-interference.

From our findings, it can broadly be established that priority in the Washington Consensus is more effective at fighting capital flight compared to the Beijing Model because whereas political governance (and/or constituents) negatively affect capital flight, and economic governance (and/or constituents) has the opposite effect.

\subsubsection{Corruption-control as the most effective governance weapon}

In terms of significance and magnitude of significance of estimated coefficients, we have established that corruption-control is the most significant deterrent to capital flight. This is probably because it is the 'end-game', 'last resort' or 'final phase' in the fight against capital flight. Corruption-control as the best governance weapon has been confirmed in recent software piracy (Andrés \& Asongu, 2013) and African conflicts/crimes (Asongu \& KodilaTedika, 2016) literature. In essence: (i) leaders can be voted into office through quasidemocratic mechanisms involving the majority of the population through vote-buying (political governance) and (ii) elected leaders could formulate legislative rules but overseeing citizens who are violating those rules substantially depends on the incorruptibility of government/public officers. Moreover, even the enforcement of rules by courts via sanctions on culprits who are caught in activities that are conducive to capital flight, are contingent on judges' incorruptibility. Citizens may express themselves as they wish within a society. However, only in the absence of corruption can: (i) credible leaders be voted into offices, (ii) genuine laws adopted by the legislature, (iii) government officers credibly enforce laws passed by the legislature, (iv) law enforcement officials take embezzlers of public commodities to courts and (v) judges inflict appropriate sanctions on government officials violating the law (especially in terms of trade misinvoicing and transfer mispricing).

As a policy implication, the findings established in the inquiry indicate that capital flight in Africa can be brought under control if the fight against corruption is enhanced by the governments of sampled countries. Such efforts in corruption-control would go a long a way to improving the investment climate that is required for economic prosperity, equitable distribution of wealth and sustainable progress in the post-2015 development agenda. 


\section{Conclusion and future research directions}

This study has investigated the effect of governance on capital flight by bundling and unbundling governance. The empirical evidence is based on 37 African countries for the period 1996-2010 and the Generalised Method of Moments. Governance is bundled by principal component analysis, namely: (i) political governance from political stability and 'voice and accountability'; (ii) economic governance from government effectiveness and regulation quality and (iii) institutional governance from corruption-control and the rule of law. The following findings are established. (i) Political stability and 'voice and accountability' reduce capital flight while the effect of political governance is not significant. (ii) Economic governance increases capital flight whereas the effects of regulation quality and government effectiveness are not significant. (iii) Corruption-control and institutional governance negatively affect capital flight whereas the impact of the rule of law is not significant. (iv) Corruption-control is the most effective governance weapon in the fight against capital flight. (v) Priority in the Washington Consensus is more effective at fighting capital flight compared to the Beijing Model. Policy implications are discussed.

Future studies can improve the extant literature by assessing if the established linkages withstand empirical scrutiny when conditional distributions of capital flight and governance are considered. In essence, articulating how initial levels in governance and capital flight affect established linkages is important because blanket capital flight policies based on mean values of dependent and independent variables may not be effective unless they are contingent on their initial levels. 


\section{Appendices}

Appendix 1: Variable Definitions

\begin{tabular}{|c|c|c|c|}
\hline Variables & Signs & Variable Definitions (Measurements) & Sources \\
\hline Capital Flight & Capf. & Ln of Capital Flight (constant of 2010), & $\begin{array}{l}\text { Ndikumana \& } \\
\text { Boyce (2012a) }\end{array}$ \\
\hline Political Stability & PolSta & $\begin{array}{l}\text { "Political stability/no violence (estimate): measured as the } \\
\text { perceptions of the likelihood that the government will be } \\
\text { destabilized or overthrown by unconstitutional and violent } \\
\text { means, including domestic violence and terrorism" }\end{array}$ & World Bank (WDI) \\
\hline $\begin{array}{l}\text { Voice \& } \\
\text { Accountability }\end{array}$ & $\mathrm{V} \& \mathrm{~A}$ & $\begin{array}{l}\text { "Voice and accountability (estimate): measures the extent to } \\
\text { which a country's citizens are able to participate in selecting } \\
\text { their government and to enjoy freedom of expression, freedom } \\
\text { of association and a free media". }\end{array}$ & World Bank (WDI) \\
\hline Political Governance & Polgov & $\begin{array}{l}\text { First Principal Component of Political Stability and Voice \& } \\
\text { Accountability. The process by which those in authority are } \\
\text { selected and replaced. }\end{array}$ & PCA \\
\hline $\begin{array}{l}\text { Government } \\
\text { Effectiveness }\end{array}$ & Gov. E & $\begin{array}{l}\text { "Government effectiveness (estimate): measures the quality of } \\
\text { public services, the quality and degree of independence from } \\
\text { political pressures of the civil service, the quality of policy } \\
\text { formulation and implementation, and the credibility of } \\
\text { governments' commitments to such policies". }\end{array}$ & World Bank (WDI) \\
\hline Regulation Quality & RQ & $\begin{array}{l}\text { "Regulation quality (estimate): measured as the ability of the } \\
\text { government to formulate and implement sound policies and } \\
\text { regulations that permit and promote private sector } \\
\text { development". }\end{array}$ & World Bank (WDI) \\
\hline $\begin{array}{l}\text { Economic } \\
\text { Governance }\end{array}$ & Ecogov & $\begin{array}{l}\text { "First Principal Component of Government Effectiveness and } \\
\text { Regulation Quality. The capacity of government to formulate } \\
\& \text { implement policies, and to deliver services". }\end{array}$ & PCA \\
\hline Rule of Law & RL & $\begin{array}{l}\text { "Rule of law (estimate): captures perceptions of the extent to } \\
\text { which agents have confidence in and abide by the rules of } \\
\text { society and in particular the quality of contract enforcement, } \\
\text { property rights, the police, the courts, as well as the likelihood } \\
\text { of crime and violence". }\end{array}$ & World Bank (WDI) \\
\hline Corruption-Control & $\mathrm{CC}$ & $\begin{array}{l}\text { "Control of corruption (estimate): captures perceptions of the } \\
\text { extent to which public power is exercised for private gain, } \\
\text { including both petty and grand forms of corruption, as well as } \\
\text { 'capture' of the state by elites and private interests". }\end{array}$ & World Bank (WDI) \\
\hline $\begin{array}{l}\text { Institutional } \\
\text { Governance }\end{array}$ & Instgov & $\begin{array}{l}\text { First Principal Component of Rule of Law and Corruption- } \\
\text { Control. The respect for citizens and the state of institutions } \\
\text { that govern the interactions among them }\end{array}$ & PCA \\
\hline Trade Openness & Trade & Export plus Imports of Goods and Services (\% of GDP) & World Bank (WDI) \\
\hline GDP growth & GDPg & Gross Domestic Product (GDP) growth (annual \%) & World Bank (WDI) \\
\hline Inflation & Infl. & Consumer Price Index (annual \%) & World Bank (WDI) \\
\hline Foreign investment & FDI & Foreign Direct Investment inflows (\% of GDP) & World Bank (WDI) \\
\hline Public Investment & Pub.I & Gross Public Investment ( $\%$ of GDP) & World Bank (WDI) \\
\hline
\end{tabular}

WDI: World Bank Development Indicators. PCA: Principal Component Analysis. 
Appendix 2: Summary statistics (three year averages from 1996-2010)

\begin{tabular}{llllll}
\hline & Mean & SD & Minimum & Maximum & Observations \\
\cline { 2 - 6 } Capital flight (log) & 10.073 & 0.763 & 6.871 & 11.704 & 137 \\
Political Stability & -0.647 & 0.949 & -2.908 & 1.188 & 185 \\
Voice \& Accountability & -0.676 & 0.670 & -1.850 & 0.915 & 185 \\
Political Governance & -0.067 & 1.272 & -2.818 & 2.683 & 185 \\
Government Effectiveness & -0.629 & 0.579 & -1.960 & 0.740 & 185 \\
Regulation Quality & -0.627 & 0.564 & -2.123 & 0.742 & 185 \\
Economic Governance & 0.191 & 1.221 & -2.937 & 3.139 & 185 \\
Rule of Law & -0.697 & 0.641 & -2.070 & 0.706 & 185 \\
Control of Corruption & -0.564 & 0.568 & -1.978 & 0.992 & 185 \\
Institutional Governance & 0.058 & 1.313 & -3.088 & 3.313 & 185 \\
Trade Openness & 76.074 & 39.929 & 20.979 & 250.954 & 178 \\
GDP growth & 4.435 & 3.530 & -11.271 & 19.818 & 180 \\
Inflation & 73.344 & 663.372 & -45.112 & 8603.275 & 173 \\
Foreign Direct Investment inflows & 3.930 & 5.299 & -4.112 & 33.738 & 143 \\
Public Investment & 7.265 & 3.778 & 0.361 & 19.961 & 165
\end{tabular}

S.D: Standard Deviation.

Appendix 3: Correlation matrix (Uniform sample size :102)

\begin{tabular}{|c|c|c|c|c|c|c|c|c|c|c|c|c|c|c|c|}
\hline \multicolumn{3}{|c|}{ Political governance } & \multicolumn{3}{|c|}{ Economic governance } & \multicolumn{3}{|c|}{ Institutional governance } & \multirow[b]{2}{*}{ Trade } & \multicolumn{3}{|c|}{ Control variables } & \multirow{2}{*}{\multicolumn{2}{|c|}{$\begin{array}{c}\text { Capital } \\
\text { Flight }\end{array}$}} & \\
\hline PS & VA & Polgov & GE & RQ & Ecogov & $\mathrm{CC}$ & RL & Instgov & & GDPg & Infl. & FDI & & & \\
\hline \multirow[t]{15}{*}{1.000} & 0.739 & 0.928 & 0.686 & 0.683 & 0.710 & 0.728 & 0.796 & 0.791 & 0.280 & 0.009 & -0.229 & 0.004 & 0.420 & -0.194 & PS \\
\hline & 1.000 & 0.936 & 0.748 & 0.735 & 0.769 & 0.726 & 0.773 & 0.778 & 0.023 & -0.025 & -0.160 & -0.005 & 0.256 & -0.013 & VA \\
\hline & & 1.000 & 0.770 & 0.761 & 0.794 & 0.780 & 0.841 & 0.841 & 0.159 & -0.008 & -0.207 & -0.0006 & 0.360 & -0.109 & Polgov \\
\hline & & & 1.000 & 0.871 & 0.970 & 0.856 & 0.878 & 0.901 & -0.010 & 0.012 & -0.156 & -0.145 & 0.270 & 0.201 & GE \\
\hline & & & & 1.000 & 0.964 & 0.756 & 0.819 & 0.819 & -0.028 & -0.102 & -0.264 & -0.230 & 0.109 & 0.139 & $\mathrm{RQ}$ \\
\hline & & & & & 1.000 & 0.834 & 0.880 & 0.891 & -0.019 & -0.044 & -0.215 & -0.193 & 0.203 & 0.174 & Ecogov \\
\hline & & & & & & 1.000 & 0.848 & 0.964 & 0.124 & -0.051 & -0.173 & -0.060 & 0.292 & -0.024 & $\mathrm{CC}$ \\
\hline & & & & & & & 1.000 & 0.957 & 0.068 & -0.023 & -0.221 & -0.050 & 0.373 & 0.027 & RL \\
\hline & & & & & & & & 1.000 & 0.101 & -0.039 & -0.204 & -0.057 & 0.342 & 0.001 & Instgov \\
\hline & & & & & & & & & 1.000 & -0.105 & 0.210 & 0.394 & 0.274 & -0.142 & Trade \\
\hline & & & & & & & & & & 1.000 & 0.122 & 0.061 & 0.222 & 0.097 & GDPg \\
\hline & & & & & & & & & & & 1.000 & 0.207 & -0.054 & 0.223 & Infl. \\
\hline & & & & & & & & & & & & 1.000 & 0.072 & -0.040 & FDI \\
\hline & & & & & & & & & & & & & 1.000 & -0.292 & Pub. I \\
\hline & & & & & & & & & & & & & & 1.000 & Cap. Flight \\
\hline
\end{tabular}

PS: Political Stability/Non violence. VA: Voice \& Accountability. Polgov: Political Governance. GE: Government Effectiveness. RQ: Regulation Quality. Ecogov: Economic Governance. CC: Corruption-Control.RL: Rule of Law. Instgov: Institutional Governance. Trade: Trade Openness. GDPg: GDP growth. Infl: Inflation. FDI: Foreign Direct Investment inflows. Pub.I: Public Investment. Cap. Flight: Capital Flight. 


\section{References}

Andrés, R. A, \& Asongu, S. A., (2013). "Fighting Software Piracy: Which Governance Tools Matter in Africa?", Journal of Business Ethics 118(3), pp. 667-682.

Andrés, R. A, Asongu, S. A., Amavilah, V. H., (2015). “The Impact of Formal Institutions on Knowledge Economy”, Journal of the Knowledge Economy, 6(4), pp. 1034-1062.

Arellano, M., \& Bond, S., (1991). "Some tests of specification for panel data: Monte Carlo evidence and an application to employment equations". The Review of Economic Studies, 58(2), pp. 277-297.

Arellano, M., \& Bover, O., (1995). "Another look at the instrumental variable estimation of error-components models", Journal of Econometrics, 68(1), pp. 29-52.

Asongu, S. A., (2013, October), "Fighting African capital flight: timelines for the adoption of common policies", The Empirical Economics Letters,

http://www.eel.my100megs.com/volume-12-number-10.htm (Accessed: 09/08/2015).

Asongu, S., (2014). "Fighting African Capital Flight: Empirics on Benchmarking Policy Harmonization", The European Journal of Comparative Economics, 11 (1), pp. 93-122.

Asongu, S. A., (2015). "Rational Asymmetric Development, Piketty and the Spirit of Poverty in Africa". African Governance and Development Institute Working Paper No. 15/006, Yaoundé.

Asongu, S. A., (2016). "Determinants of Growth in Fast Developing Countries: Evidence from Bundling and Unbundling Institutions”, Politics \& Policy, 44(1), pp. 97-134.

Asongu, S. A., \& Amankwah-Amoah, J., (2016). "Military expenditure, terrorism and capital flight: Insights from Africa", African Governance and Development Institute Working Paper No. 16/018, Yaoundé.

Asongu, S. A., \& De Moor, L., (2016). "Financial globalisation dynamic thresholds for financial development: evidence from Africa", The European Journal of Development Research, DOI:10.1057/ejdr.2016.10.

Asongu, S. A., \& Kodila-Tedika, O., (2016). "Fighting African Conflicts and Crimes: Which Governance Tools Matter?” International Journal of Social Economics, 43(5), pp. 466-485.

Asongu, S. A., \& Nwachukwu, J., (2016a). "Revolution empirics: predicting the Arab Spring” Empirical Economics, 51(2), pp. 439-482.

Asongu, S. A, \& Nwachukwu, J. C., (2016b). "The Mobile Phone in the Diffusion of Knowledge for Institutional Quality in Sub Saharan Africa", World Development, 86(October), pp. 133-147.

Asongu, S. A, \& Nwachukwu, J. C., (2016c). "Foreign aid and governance in Africa", International Review of Applied Economics, 30(1), pp. 69-88. 
Ba, J., \& Ng S., (2006). "Confidence intervals for diffusion index forecasts and inference for factor-augmented regression", Econometrica, 74(4), pp. 1133-1150.

Bai, J., (2003). "Inferential theory for factor models of large dimensions". Econometrica, 71 (1),pp.135-173.

Bai, J., (2009). "Panel data models with interactive fixed effects". Econometrica, 77(4), pp. 1229-1279.

Baltagi, B. H., (2008). "Forecasting with panel data", Journal of Forecasting, 27(2), pp. 153173.

Bartels, F. L., Alladina, S. N., and Lederer, S., (2009). "Foreign direct investment in subSaharan Africa: Motivating factors and policy issues". Journal of African Business, 10(2), pp. 141-162.

Beck, T., Demirgüç-Kunt, A., \& Levine, R., (2003), "Law and finance: why does legal origin matter?", Journal of Comparative Economics, 31(4), pp. 653-675.

Blundell, R., \& Bond, S., (1998). "Initial conditions and moment restrictions in dynamic panel data models", Journal of Econometrics, 87(1), pp. 115-143.

Bond, S., Hoeffler, A., \& Tample, J., (2001). "GMM Estimation of Empirical Growth Models", University of Oxford.

Boyce, J. K., \& Ndikumana L. (2011). "Capital flight from sub-Saharan Africa: linkages with external borrowing and policy options", International Review of Applied Economics, 25(2), pp. 149-170.

Boyce, J. K., \& Ndikumana L. (2012a). "Capital Flight from Sub-Saharan African Countries: Updated Estimate, 1970-2010', Political Economy Research Institute, University of Massachusetts.

http://www.peri.umass.edu/fileadmin/pdf/ADP/SSAfrica_capitalflight_Oct23_2012.pdf (Accessed: 09/08/2015).

Boyce, J. K., \& Ndikumana L. (2012b). "Rich Presidents of Poor Nations: Capital Flight from Resource-Rich Countries in Africa', Political Economy Research Institute University of Massachusetts.

http://concernedafricascholars.org/wp-content/uploads/2012/11/caploss01-ndiku-14th.pdf (Accessed: 09/08/2015).

Boyce, J. K., \& Ndikumana L., (2003). "Public Debt and Private Assets: Explaining Capital Flight from Sub-Saharan African Countries”, World Development, 31(1), pp. 107-130.

Boyce, J. K., \& Ndikumana, L. (1998). “Congo's odious debt: External borrowing and capital flight in Zaire", Development and Change, 29(2), pp. 195-217.

Boyce, J. K., \& Ndikumana, L. (2001). "Is Africa a Net Creditor? New Estimate of Capital Flight from Severely Indebted Sub-Saharan African Countries, 1970-1996”, Journal of 
Development,38(2), pp. 27-56.

Christensen, J. (2011). "The looting continues: Tax havens and corruption". Critical Perspectives on International Business, 7(2), pp.177-196.

Collier, P., Hoeffler, A. \& Pattillo, C., (2004). “Africa's Exodus: Capital Flight and the Brain Drain as Portfolio Decisions". Journal of African Economies, 13 (2), pp. 15-54.

Darley, W. K., (2012). "Increasing sub-Saharan Africa's share of foreign direct investment: Public policy challenges, strategies, and implications". Journal of African Business, pp. 13(1), 62-69.

Davies, V. (2008), "Post-war Capital Flight and Inflation". Journal of Peace Research, 45(4),pp. 519-537.

Dewan, S., \& Ramaprasad, J., (2014). "Social media, traditional media and music sales", MIS Quarterly, 38(1), pp. 101-128.

Dixit, A., (2009). "Governance Institutions and Economic Activity", American Economic Review, 99(1), pp. 5-24.

Drogendijk, R., \& Blomkvist, K., (2013). "Drivers and Motives for Chinese Outward Foreign Direct Investment in Africa", Journal of African Business, 14(2), pp. 75-84.

Efobi, U., \& Asongu, S. A., (2016). "Terrorism and Capital Flight from Africa", International Economics, 148(December), pp. 81-94.

Fukuyama, F., (2013). “What is Governance?”, Governance, 26(3), pp. 347-368.

Gani, A., (2011). "Governance and Growth in Developing Countries", Journal of Economic Issues, 45(1), pp. 19-40.

Gankou, J-M., Bendoma, M., \& Sow, M. N., (2016). "The Institutional Environment and the Link between Capital Flows and Capital Flight in Cameroon", African Development Review, 28(S1), pp. 65-87.

GTI (2014). "Global Terrorism Index: Measuring and Understanding the Impact of Terrorism", Institute for Economics and Peace, pp. 2-90.

http://www.visionofhumanity.org/sites/default/files/Global\%20Terrorism\%20Index\%20Repor t\%202014_0.pdf (Accessed: 28/04/2015).

Greenaway-McGrevy, R., Han, C., \& Sul, D., (2012). "Asymptotic distribution of factor augmented estimators for panel regression”. Journal of Econometrics, 169 (1), pp. 48-53.

Kangoye, T., (2013). "Does Aid Unpredictability Weaken Governance? Evidence From Developing Countries", The Developing Economies, 51(2), pp. 121-144.

Kelsey D \& le Roux, S., (2016), "Dragon Slaying with Ambiguity: Theory and Experiments", Journal of Public Economic Theory. doi: 10.1111/jpet.12185. 
Kwaramba, M., Mahonye, N., \& Mandishara, L., (2016). "Capital Flight and Trade

Misinvoicing in Zimbabwe”, African Development Review, 28(S1), pp. 50-64.

Jolliffe, I. T. (2002) Principal Component Analysis (2nd Ed.) New York: Springer.

Kaiser, H. F. (1974) “An index of factorial simplicity” Psychometrika 39, pp. 31-36.

Kaufmann, D., Kraay, A., \& Mastruzzi, M., (2007a). "Growth and Governance: A Reply", Journal of Politics, 69(2), pp. 555-562.

Kaufmann, D., Kraay, A., \& Mastruzzi, M., (2007b). "Growth and Governance: A Rejoinder", Journal of Politics, 69(2), pp. 570-572.

Kaufmann, D., Kraay, A \& Mastruzzi, M., (2010). "The worldwide governance indicators: Methodology and analytical Issues". World Bank Policy Research Working Paper No 5430, Washington.

Kolstad, I., \& Wiig, A., (2011). "Better the Devil You Know? Chinese Foreign Direct Investment in Africa", Journal of African Business, 12(2), pp. 31-50.

Kurtz, M., \& Schrank, A., (2007a). "Growth and Governance: Models, Measures, and Mechanisms”, Journal of Politics, 69(2), pp. 538-554.

Kurtz, M., \& Schrank, A., (2007b). "Growth and Governance: A Defense", Journal of Politics, 69(2), pp. 563-569.

Le, Q. V., \& Zak. P. J., (2006). "Political risk and capital flight". Journal of International Money and Finance, 25(2), pp. 308-329.

Le Roux, S., \& Kelsey, D., (2016). "Strategic Ambiguity and Decision-making An Experimental Study”, Department of Economics, Oxford Brookes University.

Lensink, R., Hermes, N., \& Murinde. V., (2000). 'Capital flight and political risk'

Journal of International Money and Finance, 19(1), pp. 73-92.

Lin, X., \& Farrell, C., (2013). "The Internationalization Strategies of Chinese State and Private State Enterprises in Africa", Journal of African Business, 14(2), pp. 85-95.

Love, I., \& Zicchino, L., (2006). "Financial Development and Dynamic Investment Behaviour: Evidence from Panel VAR" .The Quarterly Review of Economics and Finance, 46(2), pp. 190-210.

McKenzie C, R., \& McAleer M (1997). "On efficient estimation and correct inference in models with generated regressors: A general approach." Japanese Economic Review, 48(4), pp. 368-389.

Moulemvo, A., (2016). "Impact of Capital Flight on Public Social Expenditure in CongoBrazzaville", African Development Review, 28(S1), pp. 113-123. 
Mpenya, A. H. T., Metseyem, C., \& Epo, B. N., (2016). "Natural Resources and Capital Flight in Cameroon", African Development Review, 28(S1), pp. 88-99.

Muchai, D. N., \& Muchai, J., (2016). "Fiscal Policy and Capital Flight in Kenya", African Development Review, 28(S1), pp. 8-21.

Musila, J. W., \& Sigué, S. P., (2010). "Corruption and International Trade: An Empirical Investigation of African Countries", World Economy, 33(1), pp.129-146.

Ndiaye, A. S., \& Siri, A., (2016). "Capital Flight from Burkina Faso: Drivers and Impact on Tax Revenue”, African Development Review, 28(S1), pp. 100-112.

Ndikumana, L., (2016). "Causes and Effects of Capital Flight from Africa: Lessons from Case Studies”, African Development Review, 28(S1), pp. 2-7.

Ndikumana, L., \& Boyce, J. K., (2011a), Africa's odious debts: How foreign loans and capital flight bled a continent. London: Zed Books.

Ndikumana, L., \& Boyce, J. K., (2011b). "New estimates of capital flight from sub-Saharan African countries: Linkages with external borrowing and policy options". International Review of Applied Economics, 25(2), pp. 149-170.

Ndikumana, L., Boyce, J. \& Ndiaye, A.S. (2015). "Capital Flight: Measurement and Drivers", in Ajayi, S. I. and L. Ndikumana (Eds), Capital Flight from Africa: Causes, Effects, and Policy Issues, Oxford: Oxford University Press, 15-54.

Ndikumana, L., \& Sarr, M., (2016). "Capital flight and foreign direct investment in Africa: An investigation of the role of natural resource endowment", WIDER Working Paper No. 2016/58, Helsinki.

Nyatepe-Coo, A.A., (1994). "Capital flight in low-income sub-Saharan Africa: The effects of political climate and macroeconomic policies". Scandinavian Journal of Development Alternatives, 13(4), pp. 59-69.

Oluwatobi, S., Efobi, U.R., Olurinola, O.I., Alege, P. (2015), "Innovation in Africa: Why Institutions Matter", South African Journal of Economics, 83(3), pp. 390-410.

Oxley L, \& McAleer, M., (1993). "Econometric issues in macroeconomic models with generated regressors." Journal of Economic Surveys, 7(1), pp. 1-40.

Pagan, A., (1984). "Econometric issues in the analysis of regressions with generated regressors" International Economic Review, 25(1), pp. 221-247.

Pesaran, M. H., (2006). "Estimation and inference in large heterogeneous panels with a multifactor error structure". Econometrica 74 (4), pp. 967-1012. 
Ramiandrisoa, O. T., \& Rakotomanana, J. M., (2016). "Why Is There Capital Flight from Developing Countries? The Case of Madagascar", African Development Review, 28(S1), pp. 22-38.

Roodman, D., (2009a). "A Note on the Theme of Too Many Instruments", Oxford Bulletin of Economics and Statistics, 71(1), pp. 135-158.

Roodman, D., (2009b). "How to do xtabond2: An introduction to difference and system GMM in Stata”, Stata Journal, 9(1), pp. 86-136.

Stock, J. H. \& M. W. Watson (2002). "Forecasting using principal components from a large number of predictors". Journal of the American Statistical Association, 97 (460), pp.11671179.

Tuomi, K., (2011). "The role of the investment climate and tax incentives in the foreign direct investment decision: Evidence from South Africa". Journal of African Business, 12(1), pp. 133- 147.

Tusalem, R. F., (2015), "State Regulation of Religion and the Quality of Governance", Politics \& Policy, 43(1), pp. 94-141.

Westerlund, J., \& Urbain, J-P., (2013a). "On the estimation and inference in factor-augmented panel regressions with correlated loadings", Economic Letters, 119(3), pp. 247-250.

Westerlund, J., \& Urbain, J-P., (2013b). "On the implementation and use of factor-augmented regressions in panel data", Journal of Asian Economics, 28(October), pp. 3-11.

Westerlund, J., \& Urbain, J-P., (2012). “Cross-sectional averages versus principal components", Maastricht University, RM/11/053, Maastricht.

Weeks, J., (2012). "Macroeconomic impact of capital flows in Sub-Saharan African countries, 1980-2008”, Association of Concerned Africa Scholar Bulletin, 87, pp. 1-7.

Weeks, J., (2015). Macroeconomic impact of capital flows in Sub-Saharan Africa, in Ajayi, S.I., and Ndikumana, L., (Eds.), Capital Flight from Africa: Causes, Effects and Policy Issues. Oxford: Oxford University Press.

World Bank (2015). "World Development Indicators", World Bank Publications http://www.gopa.de/fr/news/world-bank-release-world-development-indicators-2015 (Accessed: 25/04/2015).

Yerrabati, S., \& Hawkes, D., (2015). "Economic Governance and Economic Growth in South and East Asia \& Pacific Region: Evidence from Systematic Literature Reviews and Metaanalysis". Advances in Economics and Business, 3 , pp. 1 - 21. 